Article

\title{
Examining the Relationships between Visitors Profile, Satisfaction and Revisit Intentions: Evidence from Romanian Ecotourism Destinations
}

\author{
Cristinel Petrișor Constantin *(D), Ana Ispas (D) and Adina Nicoleta Candrea
}

Citation: Constantin, C.P.; Ispas, A.; Candrea, A.N. Examining the Relationships between Visitors Profile, Satisfaction and Revisit Intentions: Evidence from Romanian Ecotourism Destinations. Land 2022, 11, 186. https://doi.org/10.3390/ land11020186

Academic Editors: María de la Cruz del Río-Rama, José Álvarez-García, Amador Durán-Sánchez and Pedro Cuesta-Valiño

Received: 24 December 2021

Accepted: 21 January 2022

Published: 25 January 2022

Publisher's Note: MDPI stays neutral with regard to jurisdictional claims in published maps and institutional affiliations.

Copyright: (C) 2022 by the authors. Licensee MDPI, Basel, Switzerland. This article is an open access article distributed under the terms and conditions of the Creative Commons Attribution (CC BY) license (https:// creativecommons.org/licenses/by/ $4.0 /)$.
Faculty of Economic Sciences and Business Administration, Transilvania University of Brașov, 500036 Brașov, Romania; ispasana@unitbv.ro (A.I.); adina.candrea@unitbv.ro (A.N.C.)

* Correspondence: cristinel.constantin@unitbv.ro; Tel.: +40-0727-39-2380
Abstract: Monitoring satisfaction levels among visitors presents an important challenge in ecotourism destinations, as it can provide useful information for tourism planning and management. The purposes of this study are (i) to identify the attribute-level satisfaction factors in the context of four ecotourism destinations from Romania, (ii) to investigate whether segments with different purposes for visiting reported different levels of satisfaction, (iii) to examine if the analyzed ecotourism destinations recorded different levels of satisfaction, and (iv) to determine if the attribute-level satisfaction factors and visitors' profiles influence the intention to revisit ecotourism destinations. The research data were collected using a survey among 1157 visitors in the analyzed destinations. An exploratory factor analysis (EFA) was computed and an analysis of variance (ANOVA) was conducted in order to determine whether significant differences in satisfaction existed across segments and across destinations. The research findings indicate three attribute-level satisfaction factors ((i) attractions and information services, (ii) amenities, (iii) conservation of natural and cultural heritage). Subsequent results revealed significant differences across visitor segments for two out of the three attribute-level satisfaction factors and across the four analyzed ecotourism destinations regarding all satisfaction factors. Furthermore, there were significant differences across visitor segments concerning the intention to revisit, however, influence of satisfaction factors on the intention to revisit the ecotourism destinations was found to be poor. The present study provides a contribution to the body of knowledge in ecotourism destination management and marketing by improving the understanding of relationships among visitors' profile, satisfaction levels, and revisiting intention.

Keywords: ecotourism destination; visitor satisfaction; attribute-level satisfaction; revisit intention; travelers profile; attractions and information services; amenities; conservation of natural and cultural heritage; survey among visitors

\section{Introduction}

Ecotourism is one of the fastest growing sectors in the tourism industry, with an annual global growth rate of 5\% [1]. The International Ecotourism Society (TIES) officially defines ecotourism as, "Responsible travel to nature areas that conserves the environment and improves the welfare of local people" [2]. Ecotourism areas became important destinations, due to their efficiency in protecting the environment and supporting education, recreation, and job creation [3]. In ecotourism destinations, the touring experience takes place within a natural environment and is directly linked to environmental features. Investigation of travel experiences and the satisfaction of visitors remains important for the long-term benefit of ecotourism products and destinations [4] as "ecotourists are likely to perceive ecotourism site visits in terms of their expressive experience rather than merely as a utilitarian transaction" [5]. The interest in studying the experiences of visitors at a destination derives from the fact these experiences act as a key driver for future behavior, due to the influence on customer satisfaction [6]. Therefore, it is necessary to understand to what 
extent the visitors are satisfied with the services provided within ecotourism destinations, and the effects of their socio-demographic and travel behavior characteristics on their satisfaction. The competitive environment requires an attainment of customer satisfaction through delivery of quality services in order to maintain business survival. Therefore, understanding visitors' profiles and possible differences in their satisfaction levels is also critical in creating a sustainable competitive advantage for ecotourism destinations. Information regarding typology and profiles of visitors allows ecotourism destination managers to optimize their approach concerning different motivations and experiences, in order to identify which types of visitors are more likely to be found in different stages of tourist areas' development [7].

However, it is highlighted in tourism literature that only few segmentation studies focused on the relationship between the segments of demand, tourist satisfaction and loyalty, thus more empirical evidence is needed $[8,9]$. In this respect, the current paper aims at identifying the above-mentioned relationships. The contribution to the body of research was developed upon three pillars. First, we tested the relationship between visitors' profiles and satisfaction levels starting from the assumption that typically, eco-visitors exhibit high levels of satisfaction regarding their eco-based experiences [10-12]. Second, the satisfaction of visitors in relationship with the ecotourism destinations was analyzed starting from findings in the literature. In the tourism industry, practitioners use tourist satisfaction levels as a basic parameter to evaluate the performance of various destination-specific tourism products [13]. Consequently, the overall satisfaction of visitors concerning a destination can be specified as a function of their satisfaction with the individual attributes of all products and services [14-16]. Third, we analyzed the influence of attribute-level satisfaction factors and visitors' profiles on revisit intentions. As researchers reveal, a better understanding of satisfaction regarding visitors in ecotourism destinations and how this impacts their future behavior can guide the provision of specialized products and services, and offer valuable marketing and management insights to hosts and managers of ecotourism destinations [11].

Improving understanding of the relationships among visitors' profiles, satisfaction, and revisit intentions will better inform the managers of ecotourism destinations on methods to adjust their services and marketing efforts to enhance visitors' satisfaction and future revisit intentions.

\subsection{Visitors' Profile}

Given the importance of ecotourism in natural protected areas, it is necessary to obtain detailed knowledge on characteristics of the demand. Market segmentation would enable tourism site managers to subdivide the tourists into segments, to comprehend their preferences better, and communicate more efficiently. Furthermore, market segmentation offers important advantages in ecotourism, considering that worldwide operators encounter clear pressures in ensuring consumers receive experiences as anticipated [17].

Certain tourism scholars consider visitors' characteristics as being relevant to the levels of satisfaction with tourism destinations and subsequently segmented the tourism market into groups of visitors sharing common characteristics such as (i) age group; (ii) number of trips taken per annum/season; (iii) education; (iv) occupation; (v) income; and (vi) purpose of trip [18]. Profiling is one of the phases in market segmentation [19]. Understanding visitors' profiles among ecotourism destinations may prove to be a strategic action in the competitive tourism market. Profiling helps to identify target markets, craft meaningful messages, and develop products and resources in such a way that meets particular demands [20]. Moreover, visitor profiles are a determining factor that influences destination management approaches for achieving multiple aspirational goals such as high visitor satisfaction and site sustainability [21].

Tourism scholars have profiled visitors from different ecotourism areas across the world: North America (e.g., [22]); South America (e.g., [23]), Africa (e.g., [24]) Asia (e.g., [25]), Australia (e.g., [26]); and Europe (e.g., [27]) using variables such as: age, education and income [22,25,26], nationality [24] motivations [23,28], on-site activities [29], 
accommodation preferences [24] and information sources [26]. Certain studies have shown high levels of satisfaction among eco-visitors [30-33].

\subsection{Satisfaction}

Satisfaction generally refers to "the consumer's response to the evaluation of the perceived discrepancy between prior expectations and the actual performance of the product as perceived after its consumption" [34]. Satisfaction toward a tourist destination can be defined as the response of tourists to the evaluation of expectations from a particular destination and the evident pleasure and performance perceived from the destination [35]. Other studies postulate satisfaction as a holistic judgment upon multiple attributes that comprise a product/service [36], which connotes "an accumulated evaluation of various components and features" [37]. Therefore, attribute satisfaction can be related to consumers' subjective judgments resulting from observations of the attributes' performance [38].

Tourism studies have previously acknowledged that attributes of a product/service/ destination are important when evaluating the purchasing behavior of individuals (i.e., the decision to visit a tourist destination, satisfaction, revisit intention, etc.) [39-43]. At the destination level, a product is presented as a mix of elements such as accommodation, entertainment, transportation, including both core and secondary attributes. During their holidays in a destination, tourists experience a wide range of attributes such as hotels, restaurants, shops, cultural, natural, and historical attractions, etc., and they may assess each attribute separately [44]. Therefore, several studies were conducted to reveal visitors' satisfaction regarding different attributes of tourist destinations [15,41,45-47]. Tourism scholars have indicated that attributes representing a feature or uniqueness of a certain place determines satisfaction [40,48]. Eusébio and Vieira [49] found that destination attributes (i.e., basic services, accessibility, and attractions) positively influences tourists' satisfaction. Similarly, Han et al., [40] found that attributes of a bicycle tourism destination were vital in the formation process of tourists' satisfaction. In a nature-based resort, Meng et al., [43] discovered that friendly/quality services and location were of significant importance in satisfaction evaluation. However, few studies have been conducted to examine satisfaction toward an ecotourism destination accounting for its attributes $[1,5,11,16,50]$. The distinctive nature of ecotourism destinations, such as the intangibility of tourist products, the multifaceted tourist experience, and the simultaneous consumption and production process, etc., make it difficult to measure visitors' satisfaction.

Various research articles presented in the literature have used several destination attributes to measure visitors' satisfaction [51,52] and reported evidence of the relationship between destination attribute satisfaction and behavioral intentions, including intentions to revisit and recommend [15]. It is important to consider the analysis of tourist satisfaction for the management of ecotourism destinations, given that the greater the degree of satisfaction, the greater the probability they will repeat the purchase of the product/service, and that they will encourage others to do so [4].

Previous studies mention high general satisfaction levels in the case of visitors among ecotourism destinations (66\% of a sample of eco-visitors at New Zealand's Pirongia Forest Park [12]; 60\% of eco-visitors who visited Kenya's Amboseli National Park were satisfied while only 4\% were dissatisfied [30]). Akama and Kieti [31], Moscardo [32], and Okello and Yerian [33] all illustrated high levels of satisfaction among eco-visitors.

\subsection{Relationship between Destination Satisfaction and Revisit Intentions}

Destination satisfaction is an overall evaluation of the extent to which a specific destination is able to meet tourists' expectations [53,54]. It is one of the most important factors that determine a destination's success as visitors' satisfaction positively influences their loyalty [14,55-57].

Travelers' intentions to revisit a destination are considered a critical factor in the tourism industry [58]. Antón et al., [37] distinguished intention to revisit a destination from intention to recommend, insisting that travelers may intend to recommend a place to 
others although they themselves had no intention to revisit the location. In light, this study, similar to the one conducted by Moon and Han [59] (analyzing Chinese travelers' revisiting intention to an island destination) uses revisit intention as a proxy for actual behaviors instead of combining other indicators of behavioral intentions such as recommendation to others.

It is generally believed that satisfied tourists are more likely to return to the same destination $[14,44,60]$. However, Um et al., [61] found that satisfaction was not a sound indicator of revisit intention. Dolnicar et al., [60] argue that in the context of tourism services, satisfaction does not necessarily lead to positive behavioral intention, especially with respect to personal intentions to return. In the same vein, Kozak et al., [62] claim that one of the certainties in tourism is that many tourists will visit only once. Repeated visits to tourist destinations are relatively rare owing to considerable travel time, cost constraints, and the variety of available alternative destinations [63]. Thus, there is a need for additional research related to satisfaction and future behavioral intentions in the case of tourist destination [35]. Furthermore, studies conducted within the field of ecotourism destinations are scarce $[4,11,64,65]$ and a new analysis of the relations between tourist satisfaction and revisit intentions to an ecotourism destination will help to respond to these ambiguities.

It is important to note that the level of tourism development in different destinations is not identical and thus, the impact of visitors' satisfaction on their intentions to revisit will differ. Furthermore, different visitor segments of a certain destination may have various satisfaction levels and distinct behavioral intentions.

Therefore, in order to achieve the overall purpose of the present study, the following research objectives were established:

O1: to identify the attribute-level satisfaction factors in the context of four ecotourism destinations from Romania,

O2: to investigate whether segments with different visit purposes report different levels of satisfaction,

O3: to examine if the analyzed ecotourism destinations recorded different levels of satisfaction,

O4: to determine if the attribute-level satisfaction factors and visitors' profile influence the intention to revisit the ecotourism destinations.

The paper is structured in five sections: the Introduction, which presents the context of the study and the current state of the research field; the Materials and Methods section, which describes the study context and the methodology; the Results section, which presents the findings of the research, followed by the Discussion section and the Conclusion.

\section{Materials and Methods}

The research was conducted by the Association of Ecotourism in Romania (AER) with the aim to find relevant information about visitors' profiles in Romanian ecotourism destinations, their satisfaction with the main attributes of these destinations and the revisit intentions, in order to find appropriate solutions that improve destination marketing and management. AER was supported in its efforts by the Romanian-American Foundation, the Romanian Partnership Foundation, and the Swiss-Romanian Cooperation Programme. The process of data analysis was performed with the help of specialists from Transilvania University of Brasov, Romania. The data regarding visitors' satisfaction collected for 15 satisfaction items were pre-processed in order to handle the missing values and outliers. Data processing starts with identification of the attribute-level satisfaction factors by using exploratory factor analysis (EFA). Next, these factors were analyzed in relation to the main visitor segments to identify significant differences between them using analysis of variance (ANOVA). Finally, the influences of attribute-level satisfaction factors as well as the influence of visitors' profiles on revisit intentions were tested using discriminant analysis and Pearson's chi-square test. 


\subsection{Setting the Scene: Romanian Ecotourism Destinations and Visitors Profile}

Romania has a unique and rich natural heritage, which creates multiple opportunities for ecotourism. The country hosts almost half of the European (excluding Russia) population of large carnivores (bear, wolf and lynx) [66]. Moreover, the Romanian territory hosts half of the Carpathian mountain range as well as the Danube Delta, which is the most important wetland in Europe. In addition to this rich natural heritage, Romania preserves an original and authentic cultural heritage, especially in rural areas situated near natural protected areas, which were successfully integrated in ten ecotourism destinations.

The Romanian National Tourism Authority [67] defines the ecotourism destination as a tourism destination that respects the following principles: (1) the destination projects a responsible marketing image; (2) businesses with a sustainable management predominate in the destination; (3) there is a real support for local communities within the destination; (4) tourists and locals are made aware of and informed about the natural characteristics of the destination; (5) clear nature conservation measures are implemented within the destination. The ecotourism destination includes at least a protected area and the local communities around or within it, including the protected area administrator in the management of the whole destination. The management of the destination focuses on tourism products, small-scale infrastructure development, and marketing holding sustainability and nature conservation as core values. The ecotourism destinations in Romania were developed and promoted by the Association of Ecotourism in Romania (AER) in partnership with other governmental and non-governmental stakeholders [68]. AER is a non-governmental organization, based on a partnership for nature conservation and tourism development in Romania. It brings together tourism associations, non-governmental organizations for local development and nature conservation, guesthouses and tourism agencies. The innovative concept promoted by AER is to rally the public and private sectors in a partnership aimed at nature conservation and sustainable tourism development. AER is increasingly interested in studying the degree of satisfaction regarding ecotourism products in order to ensure that the experience provided to visitors fulfills or even exceeds their expectations [69].

The present study focuses on four ecotourism destinations in Romania, which were considered appropriate for the purpose of this research, considering they are located within different geographical areas of the country. A comparative analysis of the existing tourism infrastructure within the studied ecotourism destinations is presented in Table 1.

Table 1. Tourism infrastructure within the studied ecotourism destinations.

\begin{tabular}{ccccc}
\hline \multirow{2}{*}{ Indicators } & \multicolumn{2}{c}{ Ecotourism Destination } \\
\cline { 2 - 5 } & Eco Maramures, & Trara Dornelor & $\begin{array}{c}\text { Pădurea } \\
\text { Craiului }\end{array}$ & $\begin{array}{c}\text { Transylvanian } \\
\text { Highlands }\end{array}$ \\
\hline $\begin{array}{c}\text { No. of accommodation } \\
\text { units }\end{array}$ & 134 & 227 & 33 & 82 \\
$\begin{array}{c}\text { No. of beds } \\
\text { No. of visitor centres and } \\
\text { tourist information offices }\end{array}$ & 1805 & 4692 & 729 & 1421 \\
\hline Source: AER. & 5 & 2 & 5 & 3 \\
\hline
\end{tabular}

Pădurea Craiului is located in the western part of the Carpathians and represents a land of caves, spectacular gorges and waterfalls, extensive forests and wildflower meadows. The caves conceal traces of human life that date from ancient times and old wooden churches, water mills and traditional households combine to form an idyllic scenery in its rural area [69]. Visitors may choose from a wide range of nature-based activities within the destination: cycling, trekking, climbing, via ferrata, caving, rafting, and horseback riding. The destination holds few places of accommodation (33 units) and five tourist information centers.

The Transylvanian Highlands are situated in the center of the country and include the second largest Natura 2000 site in Romania [69]. It is an area which best displays the Saxon culture in Romania and includes several villages with fortified churches, some 
of which are recognized as UNESCO Heritage sites (Biertan, Saschiz, Valea Viilor and Viscri). It is the largest protected area in Transylvania, where thousands of bird species nest, a region with High Nature Value farms, with extremely varied biodiversity, where traditional agricultural practices are preserved. Moreover, it offers an impressive cycling infrastructure with more than $500 \mathrm{~km}$ of trails, which is used by trekkers and, wildlife and culture enthusiasts. The destination includes 82 accommodation units and 3 tourist information centers.

Eco Maramures is a small destination situated in Maramures County, in the northwestern part of Romania. The activities on offer to visitors include nature-based activities such as cycling, climbing, paragliding, skiing, as well as cultural experiences within authentic rural areas, including wooden churches which are included in the UNESCO heritage list. Although it is a small area, the accommodation capacity totals 1805 beds in 134 units and holds five tourist information centers.

Tara Dornelor is located in the north-eastern part of Romania and partially overlaps with the Călimani National Park. Visitors may choose from a wide range of nature-based activities within the destination: cycling, trekking, crafting, paragliding and horseback riding. This destination has a long history in developing tourism, especially due to the Vatra Dornei spa and a winter sports resort which acts as a service hub for the area. This fact is also reflected in the accommodation capacity at the destination level, which totals 4692 places in 227 accommodation units. The area benefits from four interpretation trails, and one tourist information center in Vatra Dornei. It is the only analyzed destination which has a visitor center located within the administrative headquarters of the Călimani National Park.

A map containing the Romanian ecotourism destinations is presented in Figure 1. The locations of the destinations described above are colored in red. An interactive version of this map, on which the main landmarks of each destination can be accessed, is presented on the AER website [69].

As projected in the literature, the conventional profiles of eco-visitors are middle-aged and generally well educated [31,70,71], which are also found in visitors' profiles from Romanian ecotourism destinations, who are mainly aged 30-50 years, with a background of high education and middle income [7].

For the selected Romanian ecotourism destinations, the authors performed an "a priori" segmentation from a single characteristic, which was presented in a previous paper [7]. Four segments of visitors were computed according to the primary purpose of visit: nature travelers; culture travelers; leisure travelers, and eclectic travelers. The dominant characteristics of the named segments were: (1) nature travelers-under 50 years old, with secondary education level and a background of low and middle income, active people who visited the ecotourism destinations in order to participate in sports (skiing, ice climbing, rafting, hiking, zip lining, mountain biking, etc.), or to observe flora and fauna.; (2) culture travelers-over 50 years old, with higher incomes, higher education level and retired who were mainly interested in learning more about culture and traditions and in visiting painted churches or other heritage-based attractions; (3) leisure travelers-over 50 years old, lower income, secondary education level and retired, oriented towards soft activities such as relaxing in guesthouse courtyards or at their secondary residence, visiting friends or relatives; (4) eclectic travelers-under 50 years old, lower income, secondary education level and were mainly in transit or visited the destinations for various other purposes/preferred a broad range of activities. 


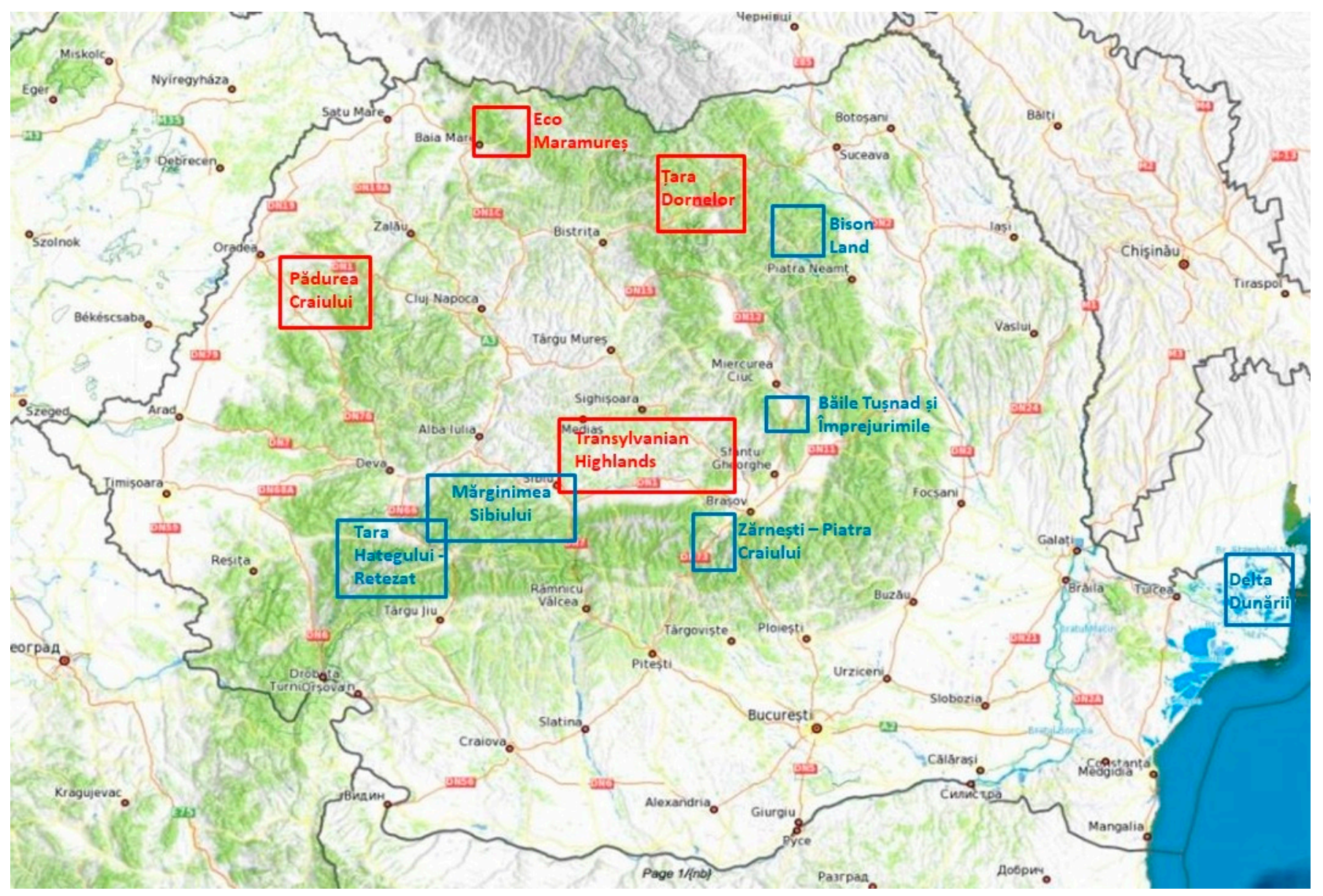

Figure 1. The geographical location of the Romanian ecotourism destinations. Source: [69].

\subsection{Research Design and Data Collection}

The research was conducted based on a survey among the visitors in the named Romanian ecotourism destinations: Eco Maramureș, Tara Dornelor, Pădurea Craiului, and Transylvanian Highlands. The research instrument for data collection was a questionnaire in which visitors were asked about: the main activities carried out in the ecotourism destination; the satisfaction of visitors with several attributes of destinations; the intention to revisit the destination; and their demographic and travel characteristics.

The satisfaction with the ecotourism destination was captured by using 15 items measured with a 5-point Likert scale with equal distance between neighbouring levels $(1=$ very dissatisfied to $5=$ very satisfied). These items were derived from previous destination studies $[14,72-74]$ and adapted to the specifics of the analyzed destinations: Cleanliness in destination; Conservation of natural heritage; Conservation of cultural heritage; Direction signs to tourist attractions; Parking near attractions; Quality of lodging; Quality of dining; Guiding; Spa facilities; Accessibility of local tourist attractions; Visitor center; Shopping facilities; Souvenirs; Interpretation and information services; Festivals and events.

A binary scale was used to capture intentions to revisit the destination and nominal scales for questions about visitors' demographics and travel characteristics. These questions referred to: age, monthly income, education, occupation, country of residence, main activities carried out in destination and frequency of visits in the destination.

The questionnaire was applied via face-to-face interviews in the analyzed ecotourism destinations and conducted by volunteer operators. The days in which the interviews were conducted were chosen randomly both within and off-season, during working days and weekends. The final sample counted 1157 visitors. 


\subsection{Data Processing}

The collected data was processed for every research objective by computing different statistical methods in IBM SPSS system. In the first stage, the data were checked for errors in order to avoid bias in the results. A number of 6 satisfaction items with a large number of missing values was excluded from analysis. Other isolated cases with random missing values were handled by imputation analysis and replaced with the mean values in SPSS. The outlier analysis focused mainly on identifying errors due to the process of entering data that needed to be corrected. As the scale used had only five levels, the effect of outliers was considered to be of low intensity, as such no outlier treatment was applied. It was preferred to maintain the observed values given that the extreme values were few in number.

An exploratory factor analysis (EFA) was used "to identify the attribute-level satisfaction factors in the context of four ecotourism destinations from Romania (O1)". Its scope was to reduce the number of items regarding the visitors' satisfaction to a small number of factors that contained the same information but were uncorrelated [75]. Thus, three factors which represented the attribute-level satisfaction factors [76] were obtained. These factors were selected after excluding 6 items from the analysis due to a large number of missing cases that distorted the results. In this respect, the EFA was computed based on 9 items: Cleanliness in destination; Conservation of natural heritage; Conservation of cultural heritage; Direction signs to tourist attractions; Parking near attractions; Quality of lodging; Quality of dining; Accessibility of local tourist attractions; Interpretation and information services.

The reliability analysis of the resulting scale based on Cronbach's alpha coefficient returned a value of 0.72 , which confirmed the internal consistency of the construct [77]. The extraction methods included a principal component analysis with varimax rotation and the suitability of data for this method was evaluated by computing Kaiser-Meyer-Olkin (KMO) Measure of Sampling Adequacy and Bartlett's Test of Sphericity [78].

Secondly, this paper aimed "to investigate whether segments with different visit purpose report different levels of satisfaction (O2)". The analysis of variance (ANOVA) was used to test the statistical significance of the differences across these segments regarding the satisfaction with every attribute-level satisfaction factor. The visitor segments considered in the analysis are presented in Section 2.1: Nature travelers, Culture travelers, Leisure travelers and Eclectic travelers.

Thirdly, the study aimed "to examine if the analyzed ecotourism destinations recorded different levels of satisfaction (O3)". For this purpose, an ANOVA was computed by using the attribute-level satisfaction factors as dependent variables and the destination from which data was collected as an independent variable.

Finally, in order "to determine if the attribute-level satisfaction factors and visitors profile influence the intention to revisit the ecotourism destinations (O4)" two separate analyses were performed. Firstly, the influence of the satisfaction factors on the revisit intention (O.4.1) was tested by discriminant analysis. This method aims at identifying certain independent variables that better discriminate between the two groups [79]. The intention to revisit the ecotourism destination (Yes/No) was considered as a dependent variable (Revisit) and attribute-level satisfaction factors were set as independent variables: "Attractions and information services"(Attract); "Amenities" (Amen); "Conservation of natural and cultural heritage" (Conserv). The following discriminant function was considered for the relationship between the two categories of variables and the significance of function coefficients was tested using ANOVA:

$$
\text { Revisit }=\beta_{0}+\beta_{1} \times \text { Attract }+\beta_{2} \times \text { Amen }+\beta_{3} \times \text { Conserv }
$$

Furthermore, the relationship between the 4 considered segments and the revisit intention (O.4.2) was analyzed based on cross-tabulation and Pearson's chi-square test. 


\section{Results}

\subsection{Demographic and Travel Characteristic of the Sample}

The structure of the sample according to the visitors' demographics and travel characteristics, resulting from the survey in the analyzed ecotourism destinations is presented in Table 2. Most of the interviewed subjects were active people $(77.5 \%)$, with a medium income $(32.7 \%)$ and higher education (70.8\%), aged between $30-50$ years old (56.2\%). Regarding the country of residence, the majority of visitors were Romanians (79.9\%), while international visitors represented $20.1 \%$ of the total sample [7].

Table 2. The sample structure on demographic and travel characteristics.

\begin{tabular}{|c|c|}
\hline Characteristics & $\%$ from Total Sample \\
\hline \multicolumn{2}{|l|}{ Age } \\
\hline Under 18 years & $1.6 \%$ \\
\hline 18-29 years & $20.5 \%$ \\
\hline $30-50$ years & $56.2 \%$ \\
\hline $51-65$ years & $17.8 \%$ \\
\hline Over 65 years & $3.9 \%$ \\
\hline \multicolumn{2}{|l|}{ Monthly income } \\
\hline Under EUR 215 & $5.2 \%$ \\
\hline EUR 215-430 & $19.9 \%$ \\
\hline EUR 431-645 & $32.7 \%$ \\
\hline EUR 646-1077 & $23.0 \%$ \\
\hline Over EUR 1077 & $19.2 \%$ \\
\hline \multicolumn{2}{|l|}{ Education } \\
\hline Lower-secondary education & $1.7 \%$ \\
\hline Upper and post-secondary education & $27.5 \%$ \\
\hline Higher education & $70.8 \%$ \\
\hline \multicolumn{2}{|l|}{ Occupation } \\
\hline Active people & $77.5 \%$ \\
\hline Retired & $12.8 \%$ \\
\hline Inactive people & $9.7 \%$ \\
\hline \multicolumn{2}{|l|}{ Country of residence } \\
\hline Romania & $79.9 \%$ \\
\hline Other countries & $20.1 \%$ \\
\hline \multicolumn{2}{|l|}{ Visitor segments according the visit purpose } \\
\hline Nature travellers & $41.7 \%$ \\
\hline Culture travellers & $29.5 \%$ \\
\hline Leisure travellers & $15.0 \%$ \\
\hline Eclectic travellers & $13.8 \%$ \\
\hline \multicolumn{2}{|l|}{ Ecotourism destination } \\
\hline Eco Maramureș & $31.4 \%$ \\
\hline Țara Dornelor & $20.5 \%$ \\
\hline Pădurea Craiului & $30.6 \%$ \\
\hline Transylvanian Highlands & $17.5 \%$ \\
\hline
\end{tabular}

Source: [7]

In order to achieve the research objectives only the variables "Visitor segments according visit purpose" and "Ecotourism destination" presented in Table 2 were used in computing the research results. 


\subsection{Attribute-Level Satisfaction Factors}

The computed means and standard deviation for every satisfaction item are presented in Table 3. All items recorded mean scores higher than 3 points (neutral level) on a 5-level scale ( 5 = very satisfied). The minimum value obtainable for every satisfaction item is 1 point and the maximum is 5 points on a 5 -level scale.

Table 3. Descriptive statistics of satisfaction items.

\begin{tabular}{llc}
\hline \multicolumn{1}{c}{ Satisfaction Items } & Mean & SD \\
\hline Cleanliness in destination & 3.9537 & 0.83531 \\
Conservation of natural heritage & 4.1639 & 0.73399 \\
Conservation of cultural heritage & 3.9611 & 0.75917 \\
Direction signs to tourist attractions & 3.7172 & 0.89744 \\
Parking near attractions & 3.6234 & 0.97545 \\
Quality of lodging & 4.3791 & 0.65933 \\
Quality of dining & 4.3906 & 0.75040 \\
Guiding & 4.3437 & 0.88344 \\
Spa facilities & 4.1364 & 0.56023 \\
Accessibility of local tourist attractions & 3.9446 & 0.81324 \\
Visitor centres & 4.6667 & 0.57735 \\
Shopping facilities & 4.4000 & 0.63246 \\
Souvenirs & 3.9923 & 0.81489 \\
Interpretation and information services & 3.7150 & 1.02306 \\
Festivals and events & 3.8028 & 0.95048 \\
\hline
\end{tabular}

The highest means were obtained by the "Visitors centre", followed by "Shopping facilities", and "Quality of lodging" then "Quality of dining". The lowest means (under 4 points) were recorded for the items regarding "Parking near attractions", "Direction signs to tourist attractions" and "Accessibility of local tourist attractions".

EFA was used in order to "identify the attribute-level satisfaction factors in the context of four ecotourism destinations from Romania (O1)". The extraction method used was principal component analysis with varimax rotation. Only 9 satisfaction items were used (see Table 4), after the exclusion of 6 items with irrelevant responses, and a three-factor solution was computed. They had eigenvalues greater or equal to 1 and explained $60.75 \%$ of the total variance. The results of EFA are presented in Table 4.

Table 4. The results of Exploratory Factor Analysis.

\begin{tabular}{lccc}
\hline \multicolumn{1}{c}{ Satisfaction Items } & Factor 1 & $\begin{array}{c}\text { Loadings } \\
\text { Factor 2 }\end{array}$ & Factor 3 \\
\hline Accessibility of local tourist attractions & 0.661 & & \\
Interpretation and information services & 0.690 & & \\
Direction signs to tourist attractions & 0.816 & & \\
Parking near attractions & 0.618 & 0.828 & \\
Quality of lodging & & 0.864 & 0.870 \\
Quality of dining & & & 0.528 \\
Cleanliness in destination & & & 1.11 \\
Conservation of natural heritage & 2.80 & 1.55 & $12.37 \%$ \\
Conservation of cultural heritage & $31.16 \%$ & & \\
\hline Eigenvalues & & & \\
\hline Percent of variance explained & & & \\
\hline
\end{tabular}

The extraction method could be considered suitable given that Kaiser-Meyer-Olkin $(\mathrm{KMO})=0.658>0.5$ and Bartlett's Test of Sphericity returned a chi-square value of 298.57 with Sig $<0.01$.

Based on the common content of the items that contribute to the resulted factors, the attribute-level satisfaction factors were labeled as follows: Factor 1-“Attractions and 
information services", Factor 2-“Amenities", Factor 3-“Conservation of natural and cultural heritage". New variables were computed in SPSS by calculating the means of the items that contributed to a factor for each respondent. The analysis of the responses' frequency for every attribute-level satisfaction factor revealed high percentages of satisfied visitors who rated these factors with scores equal to or greater than 4 points on a 5 -level scale: Attractions and information services (52.1\%), Amenities (82.7\%) and Conservation of natural and cultural heritage $(78.1 \%)$.

\subsection{The Relationship between Visitors Segments and Satisfaction}

In order to reach the next research objective $(\mathrm{O} 2$ : to investigate whether segments with different visit purposes report different levels of satisfaction) the attribute-level satisfaction factors were analyzed in relationship with the visitor segments according to the visit purpose. The results presented in Table 5 revealed the highest general mean of satisfaction was recorded by Factor 2 "Amenities" (4.15 points), followed by Factor 3 "Conservation of natural and cultural heritage" (4.09 points), whereas Factor 1 "Attractions and information services" received the lowest satisfaction rating (3.75 points).

Table 5. The means of satisfaction factors divided by visitor segments according to travel purpose.

\begin{tabular}{|c|c|c|c|}
\hline \multirow{3}{*}{ Visitor Segments } & \multicolumn{3}{|c|}{ Attribute-Level Satisfaction Factor } \\
\hline & $\begin{array}{c}\text { Attractions and } \\
\text { Information Services }\end{array}$ & Amenities & $\begin{array}{c}\text { Conservation of Natural and } \\
\text { Cultural Heritage }\end{array}$ \\
\hline & Mean & Mean & Mean \\
\hline Nature travelers & 3.73 & 4.05 & 4.10 \\
\hline Culture travelers & 3.78 & 4.34 & 4.18 \\
\hline Leisure travelers & 3.81 & 4.04 & 3.94 \\
\hline Eclectic travelers & 3.67 & 4.09 & 3.90 \\
\hline General mean & 3.75 & 4.15 & 4.09 \\
\hline \multicolumn{4}{|l|}{ ANOVA } \\
\hline $\mathrm{F}$ & 0.985 & 12.526 & 5.438 \\
\hline Sig. & 0.399 & 0.000 & 0.001 \\
\hline
\end{tabular}

The distribution of means within the four visitor segments showed that segments with different visit purposes reported different levels of satisfaction. The results of ANOVA revealed significant differences across the four segments only for two of the three attributelevel satisfaction factors, respectively "Amenities" and "Conservation of natural and cultural heritage" (Sig < 0.01).

Among the four visitors segments, nature travelers were most satisfied with the "Conservation of natural and cultural heritage" (mean $=4.10$ points); Culture travelers were most satisfied with "Amenities" (mean $=4.34$ points) and with "Conservation of natural and cultural heritage" (mean $=4.18$ points); and Leisure travelers and Eclectic travelers rated the highest mean scores for the "Amenities" factor.

\subsection{The Relationship between the Four Ecotourism Destinations and the Level of Satisfaction}

The third research objective (O3) was "to examine if the analyzed ecotourism destinations recorded different levels of satisfaction". The means recorded for every attribute-level satisfaction factor were computed in relationship with the analyzed ecotourism destinations (see Table 6). Factor 1 "Attractions and information services" recorded the highest mean in T,ara Dornelor (3.91 points), Factor 2 "Amenities" in Eco Maramures (4.37 points) and Factor 3 "Conservation of natural and cultural heritage" in the Transylvanian Highlands (4.28 points). The results of ANOVA, presented in Table 6, revealed significant differences across the four analyzed ecotourism destinations for all attribute-level satisfaction factors $($ Sig < 0.01). 
Table 6. The means of satisfaction factors divided by analyzed ecotourism destinations.

\begin{tabular}{cccc}
\hline & \multicolumn{2}{c}{ Attribute-Level Satisfaction Factor } \\
\cline { 2 - 4 } $\begin{array}{c}\text { Ecotourism } \\
\text { Destination }\end{array}$ & $\begin{array}{c}\text { Attractions and } \\
\text { Information Services }\end{array}$ & Amenities & $\begin{array}{c}\text { Conservation of Natural and } \\
\text { Cultural Heritage }\end{array}$ \\
\cline { 2 - 4 } & Mean & Mean & Mean \\
\hline Eco Maramures & 3.90 & 4.37 & 4.07 \\
Trara Dornelor & 3,91 & 4.11 & 4.06 \\
Pădurea Craiului & 3.64 & 3.94 & 4.01 \\
Transylvanian Highlands & 3.55 & 4.14 & 4.28 \\
General mean & 3.75 & 4.15 & 4.09 \\
ANOVA & & & 6.070 \\
F & 12.286 & 21.759 & 0.000 \\
Sig. & 0.000 & 0.000 &
\end{tabular}

Eco Maramures and Tara Dornelor ecotourism destinations received the highest means for the factor "Amenities" and the lowest for "Attractions and information services", while Pădurea Craiului and Transylvanian Highlands received the highest means for the factor "Conservation of natural and cultural heritage" and the lowest for "Attractions and information services". The attribute-level satisfaction factor "Attractions and information services" recorded the lowest means among all analyzed destinations.

\subsection{The Influence of the Attribute-Level Satisfaction Factors on the Revisit Intention}

In order to determine whether the attribute-level satisfaction factors influence the intention to revisit the ecotourism destinations (O4.1), a stepwise discriminant analysis was computed. The means of the attribute-level satisfaction factors divided by the two categories of visitors according to their revisit intention are presented in Table 7.

Table 7. Descriptive statistics according to revisit intention.

\begin{tabular}{cccc}
\hline & \multicolumn{2}{c}{ Attribute-Level Satisfaction Factor } \\
\cline { 2 - 4 } Revisit Intention & $\begin{array}{c}\text { Attractions and } \\
\text { Information Services }\end{array}$ & Amenities & $\begin{array}{c}\text { Conservation of Natural and } \\
\text { Cultural Heritage }\end{array}$ \\
\cline { 2 - 4 } & Mean & Mean & Mean \\
\hline Yes & 3.78 & 4.18 & 4.07 \\
No & 3.50 & 4.09 & 4.04 \\
\hline
\end{tabular}

The descriptive statistics revealed that the travelers who intended to revisit the destinations reported higher satisfaction levels for all factors. However, according to the results returned by the stepwise discriminant analysis, the difference between their means and the means of visitors who did not express their revisit intention was statistically significant only for the factor "Attractions and information services". The remaining two factors were rejected from the model at the first iteration. The non-standardized coefficients of the resulting discriminant function are presented in Table 8.

Table 8. Canonical discriminant function coefficients.

\begin{tabular}{cc}
\hline & Function 1 \\
\hline Attract & 1.399 \\
(Constant) & -5.196 \\
\hline
\end{tabular}

According to these results, the empirical discriminant function is:

$$
\text { Revisit }=-5.196+1.399 \times \text { Attract }
$$

A direct relationship was revealed, which was statistically significant according to the ANOVA results $(\mathrm{F}=21.43$; Sig. $<0.01)$. This emphasizes that the higher the satisfac- 
tion with attraction and information services, the higher the probability of revisiting the destination achievable. According to the values of the function coefficients, a respondent should evaluate this factor by at least 4 points on a 5-level Likert scale to obtain a positive discriminant score, which is associated with an intention to revisit the destination.

Therefore, the most important determinant of respondents' revisit intention is the satisfaction with Factor 1-“Attractions and information services". Given that the other two attribute-level satisfaction factors do not bear a significant discriminant power, it can be considered that the analyzed factors have a poor influence on the intention to revisit the ecotourism destinations.

\subsection{The Relationship between the Visitors Segments and the Revisit Intention}

With regards to the influence of visitors' profiles on their intention to revisit the ecotourism destinations (O4.2), the distribution of responses obtained by cross-tabulation revealed a high percentage of visitors who intended to return to the ecotourism destination (Table 9).

Table 9. The relationship between the visitor segments and the revisit intention.

\begin{tabular}{ccccccc}
\hline $\begin{array}{c}\text { Revisit } \\
\text { Intention }\end{array}$ & $\begin{array}{c}\text { Nature } \\
\text { Travelers }\end{array}$ & $\begin{array}{c}\text { Culture } \\
\text { Travelers }\end{array}$ & $\begin{array}{c}\text { Leisure } \\
\text { Travelers }\end{array}$ & $\begin{array}{c}\text { Eclectic } \\
\text { Travelers }\end{array}$ & $\begin{array}{c}\text { Pearson } \\
\text { Chi-Square }\end{array}$ & Sig. \\
\hline Yes & $85.1 \%$ & $64.5 \%$ & $78.7 \%$ & $79.4 \%$ & 48.86 & 0.00 \\
No & $14.9 \%$ & $35.5 \%$ & $21.3 \%$ & $20.6 \%$ & & \\
\hline
\end{tabular}

Nevertheless, some differences could be observed across tourist segments. The highest percentage of respondents with revisit intentions was recorded for nature travelers, while the lowest percentage was for culture travelers. Such results could be explained by the differences between the two segments' profiles. While nature travelers were mainly Romanian visitors under the age of 50, with low and middle income and secondary education, who usually undertake many visits per year, the culture travelers were over 50 years old, retired, with high incomes, highly educated, and mainly foreign people who visited Romanian ecotourism destinations every few years.

In conclusion, visitors' profile influences their revisit intention as the relationship between the two variables is statistically significant according to the results of Chi-square test, which returned a Pearson Chi-square value equal to 48.86 and a significance level lower than 0.01 .

\section{Discussion}

The overall goal of this study was to examine the relationships between visitors' profiles, satisfaction and revisit intentions, with a focus on four Romanian ecotourism destinations. The general assumption revealed in the specialty literature was that tourists with different purposes for visits reported different levels of satisfaction and both visitor profiles and satisfaction with a tourism destination influence the intention to revisit the destination.

First, the present study aimed to "identify the attribute-level satisfaction factors in the context of four ecotourism destinations from Romania". The results revealed three attribute-level satisfaction factors: Factor 1-“'Attractions and information services", Factor 2- "Amenities", and Factor 3- "Conservation of natural and cultural heritage". These findings confirm the multifactor structure of customer satisfaction [80] and are similar to those reported by Lee [76], in the context of forest recreation tourism, who also found three factors: Factor 1-“Information services", Factor 2-"Recreation facilities", and Factor 3- "Safety and sustainability".

At the level of the analyzed ecotourism destinations, a high degree of satisfaction with Factor 3, "Conservation of natural and cultural heritage" was recorded (general mean = 4.09 points), in line with the results mentioned by Xu et al., [81]. The lowest rated satisfaction factor was Factor 1 "Attractions and information services" (general mean = 3.75 points). 
This factor reflected visitors' attitudes regarding destination attributes such as: "parking near attractions" (satisfaction mean $=3.62$ points, the lowest value registered among the 15 initial items), "interpretation and information services" (3.71 points), "direction signs to tourist attractions" (3.72 points), and "accessibility of local tourist attractions" (3.94 points). The findings reveal poor tourism spatial planning within the studied destinations in addition to the need for a better planned interpretation, which is a key issue in ecotourism development. The interpretation techniques used within the analyzed ecotourism destinations were limited to mostly guided tours, walking trails, trail side signs and maps. Tara Dornelor is the only destination which had a visitor center and four interpretation trails. Therefore, as suggested by previous studies [32], future interpretation initiatives within these destinations should provide personal connections for visitors, create clear content, and allow for alternative audiences.

Secondly, the paper aimed to "investigate whether segments with different visit purpose report different levels of satisfaction". The results showed that segments with different visit purposes reported different levels of satisfaction, but there were significant differences across the four segments only for two of the three attribute-level satisfaction factors. Visitors in ecotourism destinations were driven by specific/different visit purposes and in turn they measured their satisfaction/experiences based on such purposes. The relational outcome between specific types of segments and satisfaction will ultimately define the nature of post-purchase behavioral intentions. Observing every visitor segment, nature travelers (interested in observation of flora and fauna or skiing, ice climbing, rafting, hiking, zip lining, mountain biking etc.) were most satisfied with the "Conservation of natural and cultural heritage" (mean $=4.10$ points). However, culture travelers (interested in culture and traditions and in visiting painted churches or other heritage-based attractions) were most satisfied with "Amenities" (mean $=4.34$ points) and "Conservation of natural and cultural heritage" (mean $=4.18$ points). Leisure travelers (oriented towards soft activities such as relaxing in guesthouses or in their secondary residence) and eclectic travelers (who had a broad range of visit purposes that were not focused on the specificities of ecotourism destinations) were most satisfied with the "Amenities" factor (Quality of lodging and dining and Cleanliness in destination). The study results revealed high percentages of satisfied visitors who rated the attribute-level satisfaction factors with scores equal to or greater than 4 points on a 5-level Likert scale, similar to those reported in a number of studies conducted in other contexts [10,12,30-33,82].

Thirdly, the present paper aimed "to examine if the analyzed ecotourism destinations recorded different levels of satisfaction". The outcomes of the conducted research revealed significant differences across the four analyzed ecotourism destinations for all attribute-level satisfaction factors. These results indicated differences between the analyzed destinations regarding their tourism offers, natural and cultural heritage level of conservation, as well as the quality of their tourist information and interpretation initiatives. Moreover, similar findings were reported in other studies $[83,84]$. For example, locations with different types of on-site factors (i.e., presentation platform and support services) were found to influence visitors' perceptions and satisfaction [84].

Tourist satisfaction should be taken into account when assessing the strengths and weaknesses of a tourism destination. Such an assessment can also prove useful in forming the strategic and operational planning of tourism destinations. An examination of each destination attribute's impact on tourists' satisfaction helps identify the strengths and weaknesses of the destination. Therefore, the highest mean of satisfaction with information services was registered in Tara Dornelor, which was the only analyzed destination that held a visitor center. Eco Maramures recorded the highest mean value for the second component, related to Amenities, and Colinele Transilvaniei for the Conservation of natural and cultural area. The attribute-level satisfaction factor "Attractions and information services" recorded the lowest means in all analyzed destinations. This finding must be addressed by the AER in addition to the destination management organizations from the four analyzed areas in their future tourism strategies and planning initiatives. Within the destinations 
Pădurea Craiului and Transylvanian Highlands visitors were mostly satisfied with the factor "Conservation of natural and cultural heritage". This finding may be explained by the fact that Pădurea Craiului is an extremely picturesque natural area with spectacular gorges and waterfalls while the Transylvanian Highlands include many bucolic villages, where the cultural heritage and the traditional rural life is very well preserved. Visitors to the destinations Eco Maramures and Tara Dornelor were mainly satisfied with the existing "Amenities". This outcome is not surprising as both destinations have several accommodation units on their territory.

Regarding the influence of attribute-level satisfaction factors on the intention to revisit the ecotourism destinations, the results revealed that the most important determinant of revisit intentions was satisfaction with Factor 1- "Attractions and information services". In the present study, the values recorded for respondents' satisfaction regarding each attribute included in Factor 1 are below 4 points for all visitor segments (the lowest means within the satisfaction assessment) and for each of the four analyzed destinations. Therefore, destination management organizations should focus on this particular factor in their future initiatives, in order to boost visitors' revisit intentions. The literature has overly concentrated on revisit intention as a measure of actual visitation [57,65]. Moreover, the current study confirmed that customer satisfaction is a key factor in destination management to obtain repeat customers. Therefore, the present study confirms the significant relationship between satisfaction and loyalty which was postulated in literature [14,57].

Considering the relationship between visitors' profiles and their intention to revisit the ecotourism destinations (O.4.2), our study emphasizes that the highest percentage of respondents with revisit intentions was recorded for nature travelers, while the lowest percentage was registered for culture travelers. This outcome might be due to the fact that these destinations offer unique conditions for certain sports (e.g., there are few ecotourism destinations in Romania where visitors can do river rafting). On the other hand, culture travelers might feel less motivated to revisit certain ecotourism destinations which include particular cultural landmarks or traditions and are more interested in other types of heritagebased experiences. These findings are different from previous studies which show that segments with multiple travel motives result in higher levels of intentions to return, to recommend and relay positive experiences about the destination $[8,9,85,86]$.

\section{Conclusions and Implications}

Taking into account the results of the present research, we consider that it bears a significant contribution to the body of knowledge in the field of tourism, especially regarding the marketing and management aspects of ecotourism destinations. A distinctive feature of this article consists in the simultaneous analysis of several ecotourism destinations, which have different natural attractions, tourism facilities and management systems. It allowed us to point out that satisfaction must be considered in relationship with the destinations' attributes but it can vary significantly from destination to destination. Additionally, both satisfaction and revisit intention are significantly influenced by the visitors' profile and visit purpose. Thus, from the theoretical perspective, these relationships should be studied in-depth and interpreted with caution due to the interference of several factors that influence both satisfaction and the visitors' behaviors.

From a practical perspective, the findings of this paper offer useful management and marketing insights for managers of the analyzed ecotourism destinations that previously were not considered. Therefore, as the attribute-level satisfaction factor "Attractions and information services" recorded the lowest means among all analyzed destinations, there is an urgent need for a series of measures aimed at: the preservation of the environment; the maintenance of trails, natural heritage interpretation; the provision of hiking and cycling paths, maintenance and signage of rest areas, observation platforms, and bird watch towers. All of these initiatives must be performed with a compatible and coherent connection to the natural preservation of the ecosystems at the analyzed ecotourism destinations. This information should be accurate, as otherwise the visitors could become extremely 
dissatisfied with a resulting negative impact on general satisfaction. The provision of correct information does not increase tourist satisfaction, but misleading information will lead to extreme displeasure if later found to be inaccurate [80].

Based on the finding that the attribute-level satisfaction factor "Conservation of natural and cultural heritage" did not achieve a maximum general score for the analyzed destinations, we suggest that destination management organizations should pay much closer attention to these satisfaction attributes in order to maintain customers' positive evaluation, and/or make investments for preserving the cultural and historical values of destinations. This is also supported by the existence of protected areas within the analyzed destinations and the fact that natural features conserved within a protected landscape, is one of the key characteristics of ecotourism destinations [87].

At the level of destination attributes, low satisfaction scores were recorded by "Interpretation and information services", "Accessibility of local tourist attractions", "Direction signs to tourist attractions", and "Parking near attractions". "Interpretation and information services" are particularly relevant in ecotourism destinations, where visitors are mainly interested in outdoor recreation zones that are designed to protect fragile resources, including bike paths, hiking trails in addition to the interpretation of the natural heritage. Thus, a recommendation for destination management and marketing services is to provide sound interpretation and correct information to visitors in order to communicate to visitors in a coherent way what activities and places to observe are available visitor in the respective places.

Efficient accessibility to tourist attractions is one of the most important attributes for the development of any destination. For this reason, accessibility in terms of transportation and information should be improved in the analyzed ecotourism destinations through smart development of transportation and communication technologies. Moreover, improving and increasing the number of "Direction signs to tourist attractions" and "Parking near attractions" facilitates the implementation of good management of visitor flows, which is a key issue in ecotourism destinations. Furthermore, lodging, dining and cleanliness, need to be guaranteed at standards of high quality as these attributes were well appreciated by the respondents and their absence will reduce visitor satisfaction. The ecotourism destination management organizations from the analyzed areas need to consider these aspects when planning and managing ecotourism. Some destination attributes that received a low number of responses should also be better promoted in the analyzed destinations to increase visitors' satisfaction: spa facilities, festivals and events, souvenirs, guiding, visitor centers and shopping facilities.

This study provides a relevant contribution to the literature by highlighting the relationships between visitors' profiles, their satisfaction levels and revisit intentions. These issues were not previously studied within the context of Romanian ecotourism destinations [88-90]. The findings have vital practical significance for the Romanian ecotourism industry and public organizations such as the administrations of protected areas included within the analyzed ecotourism destinations. Firstly, regional and local stakeholders can improve ecotourism products and services to increase the satisfaction of future tourists. The analysis of visitor satisfaction with different attributes of ecotourism destinations offers the opportunity to focus managerial actions on those that can increase the attractiveness and competitiveness of the destination. This will increase visitors' intentions to revisit the destinations [91]. Secondly, the outcomes provide ecotourism managers with more comprehensive and specific market segment portraits, and more effective information to meet the differentiated needs of visitors. This information could be incorporated into future ecotourism management strategies and sustainable development strategies.

\section{Research Limitations and Future Research Directions}

The results of this investigation have their limitations, which mean that they should be interpreted within their own context rather than extrapolated to another. Therefore, its focus on a narrow geographic area serves as a limitation. In this study, four ecotourism 
destinations were chosen as study areas and the data collected were analyzed as one sample. This could be a potential limitation as the socio-demographics, motivations and satisfaction characteristics of visitors of four sites could possibly be different. Another limitation was given by the fact that visitors' loyalty was measured using a single dimension, respondents' intention to revisit the destination.

In addition, this study is limited in that the data analyzed is cross-sectional, and it would be of great value to replicate this study using longitudinal evidence. Future research in other ecotourism destinations and with visitors from other countries is needed. They may include multiple collection times to better understand how post-trip satisfaction might have evolved. Future research should include more attributes, which would provide a more comprehensive understanding of visitors' satisfaction levels and could generate other attribute-level satisfaction factors.

It is hoped that the current study can stimulate further research to better understand other relationships (e.g., between quality of visitor experience and destination image) as well as the influence these relationships may have on satisfaction and loyalty.

Author Contributions: Conceptualization, C.P.C., A.I. and A.N.C.; methodology, C.P.C., A.I. and A.N.C.; software, C.P.C.; validation, C.P.C., A.I. and A.N.C.; formal analysis, C.P.C.; investigation, C.P.C., A.I. and A.N.C.; resources, C.P.C., A.I. and A.N.C.; data curation, C.P.C.; writing-original draft preparation, C.P.C., A.I. and A.N.C.; writing-review and editing, C.P.C., A.I. and A.N.C.; visualization, C.P.C., A.I. and A.N.C.; supervision, A.I. All authors have read and agreed to the published version of the manuscript.

Funding: This research was funded by ASSOCIATION OF ECOTOURISM IN ROMANIA (AER), and the APC was funded by Transilvania University of Braşov.

Institutional Review Board Statement: Not applicable.

Informed Consent Statement: Not applicable.

Data Availability Statement: Data sharing is not applicable to this article.

Acknowledgments: The authors would like to thank Association of Ecotourism in Romania (AER) for conducting this survey.

Conflicts of Interest: The authors declare no conflict of interest.

\section{References}

1. Lu, W.; Stepchenkova, S. Ecotourism experiences reported online: Classification of satisfaction attributes. Tour. Manag. 2012, 33, 702-712. [CrossRef]

2. The International Ecotourism Society (TIES). Ecotourism Definition and Principles; The International Ecotourism Society: Washington, DC, USA, 1990.

3. Tao, T.C.; Wall, G. Tourism as a sustainable livelihood strategy. Tour. Manag. 2009, 30, 90-98. [CrossRef]

4. Castellanos-Verdugo, M.; Vega-Vazquez, M.; Oviedo-García, M.A.; Orgaz-Agüera, F. The relevance of psychological factors in the ecotourist experience satisfaction through ecotourist site perceived value. J. Clean. Prod. 2016, 124, 226-235. [CrossRef]

5. Chan, J.K.L.; Baum, T. Ecotourists' perception of ecotourism experience in Lower Kinabatangan, Sabah, Malaysia. J. Sustain. Tour. 2007, 15, 574-590. [CrossRef]

6. Kim, J. The antecedents of memorable tourism experiences: The development of a scale to measure the destination attributes associated with memorable experiences. Tour. Manag. 2014, 44, 34-45. [CrossRef]

7. Constantin, C.P.; Papuc-Damașcan, V.; Blumer, A.; Albu, R.-G.; Suciu, T.; Candrea, A.N.; Ispas, A. Profiling Visitors to Romanian Ecotourism Destinations. Sustainability 2021, 13, 2958. [CrossRef]

8. Carvache-Franco, W.; Carvache-Franco, M.; Carvache-Franco, O.; Hernández-Lara, A.B. Motivation and segmentation of the demand for coastal and marine destinations. Tour. Manag. Perspect. 2020, 34, 100661. [CrossRef]

9. Prayag, G. Paradise for who? Segmenting visitors' satisfaction with cognitive image and predicting behavioural loyalty. Int. J. Tour. Res. 2012, 14, 1-15. [CrossRef]

10. Buckley, R. Managing tourism in parks: Research priorities of industry associations and protected area agencies in Australia. $J$. Ecotourism. 2002, 1, 162-172. [CrossRef]

11. Adam, I.; Adongo, C.A.; Amuquandoh, F.E. A structural decompositional analysis of eco-visitors' motivations, satisfaction and post-purchase behavior. J. Ecotourism. 2019, 18, 60-81. [CrossRef] 
12. Pan, S.; Ryan, C. Mountain areas and visitor usage-Motivations and determinants of satisfaction: The case of Pirongia Forest Park, New Zealand. J. Sustain. Tour. 2007, 15, 288-308. [CrossRef]

13. Noe, F.P.; Uysal, M. Evaluation of outdoor recreational settings: A problem of measuring user satisfaction. J. Retail. Consum. Serv. 1997, 4, 223-230. [CrossRef]

14. Chi, C.; Qu, H. Examining the structural relationships of destination image, tourist satisfaction and destination loyalty: An integrated approach. Tour. Manag. 2008, 29, 624-636. [CrossRef]

15. Campón-Cerro, A.M.; Hernández-Mogollón, J.M.; Alves, H. Sustainable improvement of competitiveness in rural tourism destinations: The quest for tourist loyalty in Spain. J. Dest. Mark. 2017, 6, 252-266. [CrossRef]

16. Carvache-Franco, M.; Segarra-Oña, M.; Carrascosa-López, C. Segmentation and motivations in eco-tourism: The case of a coastal national park. Ocean Coast. Manag. 2019, 178, 104812. [CrossRef]

17. Zografos, C.; Allcroff, D. The environmental values of potential ecotourists: A segmentation study. J. Sustain. Tour. 2007, 15, 44-66. [CrossRef]

18. Foxall, G.R. Marketing in the Service Industries; Routledge: London, UK, 2013.

19. Perera, P.; Vlosky, R.P.; Wahala, S.B. Motivational and Behavioral Profiling of Visitors to Forest-based Recreational Destinations in Sri Lanka. Asia Pac. J. Tour. Res. 2012, 17, 451-467. [CrossRef]

20. Stange, J.; Brown, D.; Hilbruner, R.; Hawkins, D.E. Tourism Destination Management-Achieving Sustainable and Competitive Results; USAID: Washington, DA, USA, 2011.

21. Weaver, D.B. Organic, incremental and induced paths to sustainable mass tourism convergence. Tour. Manag. 2012, 33, 1030-1037. [CrossRef]

22. Deng, J.; Li, J. Self-identification of ecotourists. J. Sustain. Tour. 2015, 23, 255-279. [CrossRef]

23. Diaz-Christiansen, S.; López-Guzmán, T.; Gálvez, J.C.P.; Fernández, G.A.M. Wetland tourism in natural protected areas: Santay Island (Ecuador). Tour. Manag. Perspect. 2016, 20, 47-54. [CrossRef]

24. Kruger, M.; Van Der Merwe, P.; Saayman, M.; Slabbert, E. Understanding accommodation preferences of visitors to the Kruger National Park. Tour. Hosp. Res. 2017, 19, 170-185. [CrossRef]

25. Cui, X.; Lee, G.; Lee, S.J.; Kim, T.T. Structural Relationships among Antecedents to Perceived Value of Ecotourism for Sichuan Giant Pandas in China. Sustainability 2019, 11, 210. [CrossRef]

26. Weaver, D.B.; Lawton, L.J. Overnight Ecotourist Market Segmentation in the Gold Coast Hinterland of Australia. J. Travel Res. 2002, 40, 270-280. [CrossRef]

27. Agius, K.; Theuma, N.; Deidun, A.; Camilleri, L. Small islands as ecotourism destinations: A central Mediterranean perspective. Isl. Stud. J. 2019, 14, 115-136. [CrossRef]

28. Gu, X.P.; Lewis, B.J.; Niu, L.J.; Yu, D.P.; Zhou, L.; Zhou, W.M.; Gong, Z.; Tai, Z.; Dai, L.M. Segmentation by domestic visitor motivation: Changbai Mountain Biosphere Reserve, China. J. Mt. Sci. 2018, 15, 1711-1727. [CrossRef]

29. Hvenegaard, G.T. Using Tourist Typologies for Ecotourism Research. J. Ecotourism 2002, 1, 7-18. [CrossRef]

30. Okello, M.; D’Amour, D.; Manka, S. Tourism attractions and satisfaction of Amboseli National Park, Kenya. Tour. Anal. 2008, 13, 373-386.

31. Akama, J.; Kieti, D. Measuring tourist satisfaction with Kenya's wildlife safari: A case study of Tsavo West National Park. Tour Manag. 2003, 24, 73-81. [CrossRef]

32. Moscardo, G. Escaping the jungle: An exploration of the relationships between lifestyle market segments and satisfaction with a nature based tourism experience. J. Qual. Assur. Hosp. Tour. 2004, 5, 75-94. [CrossRef]

33. Okello, M.; Yerian, S. Tourist satisfaction in relation to attractions and implications for conservation in the protected areas of the Northern Circuit, Tanzania. J. Sustain. Tour. 2009, 17, 605-625. [CrossRef]

34. Tse, D.K.; Wilton, P.C. Models of consumer satisfaction: An extension. J. Mark. Res. 1988, 25, 204-212. [CrossRef]

35. Foroudi, P.; Akarsu, T.N.; Ageeva, E.; Foroudi, M.M.; Dennis, C.; Melewar, T.C. Promising the dream: Changing destination image of London through the effect of website place. J. Bus. Res. 2018, 83, 97-110. [CrossRef]

36. Bartikowski, B.; Llosa, S. Customer satisfaction measurement: Comparing four methods of attribute categorisations. Serv. Ind. J. 2004, 24, 67-82. [CrossRef]

37. Antón, C.; Camarero, C.; Laguna-García, M. Towards a new approach of destination loyalty drivers: Satisfaction, visit intensity and tourist motivations. Curr. Issues Tour. 2014, 20, 1-23. [CrossRef]

38. Oliver, R. Cognitive, affective, and attribute bases of the satisfaction response. J. Consum. Res. 1993, 20, 418-430. [CrossRef]

39. Han, H. Effects of in-flight ambience and space/function on air travelers' decision to select a low-cost airline. Tour. Manag. 2013, 37, 125-135. [CrossRef]

40. Han, H.; Meng, B.; Kim, W. Bike-traveling as a growing phenomenon: Role of attributes, value, satisfaction, desire, and gender in developing loyalty. Tour. Manag. 2017, 59, 91-103. [CrossRef]

41. Huang, R.; Sarigöllü, E. Assessing satisfaction with core and secondary attributes. J. Bus. Res. 2008, 61, 942-949. [CrossRef]

42. Meng, B.; Han, H. Working-holiday tourism attributes and satisfaction in forming word-of-mouth and revisit intentions: Impact of quantity and quality of intergroup contact. J. Dest. Mark. 2018, 9, 347-357. [CrossRef]

43. Meng, F.; Tepanon, Y.; Uysal, M. Measuring tourist satisfaction by attribute and motivation: The case of a nature-based resort. J. Vacat. Mark. 2008, 14, 41-56. [CrossRef] 
44. Ozdemir, B.; Aksu, A.; Ehtiyar, R.; Çizel, B.; Çizel, R.B.; İçigen, E.T. Relationships Among Tourist Profile, Satisfaction and Destination Loyalty: Examining Empirical Evidences in Antalya Region of Turkey. J. Hosp. Mark. Manag. 2012, 21, 506-540. [CrossRef]

45. Chi, C. An examination of destination loyalty: Differences between first-time and repeat visitors. J. Hosp. Tour. Res. 2012, 36, 3-24. [CrossRef]

46. Kozak, M.; Rimmington, M. Tourist Satisfaction with Mallorca, Spain, as an Off-Season Holiday Destination. J. Travel Res. 2000, 39, 259-268. [CrossRef]

47. Zabkar, V.; Brencic, M.; Dmitrovic, T. Modelling perceived quality, visitor satisfaction and behavioural intentions at the destination level. Tour. Manag. 2010, 31, 537-546. [CrossRef]

48. Tanford, S.; Jung, S. Festival attributes and perceptions: A meta-analysis of relationships with satisfaction and loyalty. Tour. Manag. 2017, 61, 209-220. [CrossRef]

49. Eusébio, C.; Vieira, A.L. Destination attributes' evaluation, satisfaction and behavioural intentions: A structural modelling approach. Int. J. Tour. Res. 2013, 15, 66-80. [CrossRef]

50. Reimer, J.K.; Walter, P. How do you know it when you see it? Community-based ecotourism in the Cardamom Mountains of southwestern Cambodia. Tour. Manag. 2013, 34, 122-132. [CrossRef]

51. Lee, T.H. A structural model to examine how destination image, attitude, and motivation affect the future behaviour of tourists. Leis. Sci. 2009, 31, 215-236. [CrossRef]

52. Su, H.J.; Cheng, K.F.; Huang, H.H. Empirical study of destination loyalty and its antecedent: The perspective of place attachment. Serv. Ind. J. 2011, 31, 2721-2739. [CrossRef]

53. Chen, C.F.; Phou, S. A closer look at destination: Image, personality, relationship and loyalty. Tour. Manag. 2013, 36, 269-278. [CrossRef]

54. Lu, L.; Chi, C.G.; Liu, Y. Authenticity, involvement, and image: Evaluating tourist experiences at historic districts. Tour. Manag. 2015, 50, 85-96. [CrossRef]

55. Chen, J.S.; Gursoy, D. An investigation of tourists' destination loyalty and preferences. Int. J. Contemp. Hosp. Manag. 2001, 13, 79-85. [CrossRef]

56. Lee, J.H.; Graefe, A.R.; Burns, R.C. Service Quality, Satisfaction, and Behavioral Intention among Forest Visitors (Special issue: Consumer Psychology of Travel/Tourism Behavior). J. Travel Tour. Mark. 2004, 17, 73-82. [CrossRef]

57. Yoon, Y.; Uysal, M. An examination of the effects of motivation and satisfaction on destination loyalty: A structural model. Tour Manag. 2005, 26, 45-56. [CrossRef]

58. da Costa Mendes, J.; Oom Do Valle, P.; Guerreiro, M.M.; Silva, J.A. The tourist experience: Exploring the relationship between tourist satisfaction and destination loyalty. Turiz. Znan. -Stručni Časopis 2010, 58, 111-126.

59. Moon, H.; Han, H. Destination attributes influencing Chinese travelers' perceptions of experience quality and intentions for island tourism: A case of Jeju Island. Tour. Manag. Perspect. 2018, 28, 71-82. [CrossRef]

60. Dolnicar, S.; Coltman, T.; Sharma, R. Do satisfied tourists really intend to come back? Three concerns with empirical studies of the link between satisfaction and behavioral intention. J. Travel Res. 2013, 54, 152-178. [CrossRef]

61. Um, S.; Chon, K.; Ro, Y. Antecedents of revisit intention. Ann. Tour. Res. 2006, 33, 1141-1158. [CrossRef]

62. Kozak, M.; Huan, T.; Beaman, J.A. Systematic Approach to Non-Repeat and Repeat Travel. J. Travel Tour. Mark. 2002, 12, 19-38. [CrossRef]

63. Michels, N.; Bowen, D. The relevance of retail loyalty, strategy and practice for leisure and tourism. J. Vacat. Mark. 2005, 11, 5-19. [CrossRef]

64. Rivera, M.A.; Croes, R. Ecotourists' loyalty: Will they tell about the destination or will they return? J. Ecotourism 2010, 9, 85-103 [CrossRef]

65. Wang, W.; Chen, J.S.; Fan, L.; Lu, J. Tourist experience and wetland parks: A case of Zhejiang, China. Ann. Tour. Res. 2012, 39, 1763-1778. [CrossRef]

66. National Tourism Research and Development Institute in Romania. National Strategy for the Development of Ecotourism in Romania 2016-2020: Context, Vision and Objectives. 2015. Available online: https://patrimoniu.gov.ro/images/turismcultural/ Romania/Strategie-ecoturism.pdf (accessed on 6 December 2021).

67. National Tourism Authority in Romania. Criteria for the Designation of Ecotourism Destinations in Romania. Available online: http:/ / turism.gov.ro/web/wp-content/uploads/2021/02/Criterii-pentru-desemnarea-Destina\%C $\%$ 9Biilor-Ecoturistice. pdf (accessed on 18 April 2020).

68. Candrea, A.N.; Herțanu, A. Developing ecotourism destinations in Romania. A case study approach. Transilv. Bull. Econ. 2015, 8, 163-174.

69. Discover Eco-Romania. About AER. Available online: https://www.eco-romania.ro/en/about-aer/ (accessed on 6 December 2021)

70. Fennell, D.A. Ecotourism, 2nd ed.; Routledge: London, UK, 2003.

71. Holden, A.; Sparrowhawk, J. Understanding the motivations of ecotourists: The case of trekkers in Annapurna, Nepal. Int. J. Tour. Res. 2002, 4, 435-446. [CrossRef]

72. Chen, C.F.; Tsai, D. How destination image and evaluative factors affect behavioural intentions? Tour. Manag. 2007, 28, 1115-1122. [CrossRef] 
73. Truong, T.L.H.; Lenglet, F.; Mothe, C. Destination distinctiveness: Concept, measurement, and impact on tourist satisfaction. J. Destin. Mark. 2018, 8, 214-231. [CrossRef]

74. Wu, C.-W. Destination loyalty modeling of the global tourism. J. Bus. Res. 2016, 69, 2213-2219. [CrossRef]

75. Hastie, T.J.; Tibshirani, R.; Friedman, J.H. The Elements of Statistical Learning: Data Mining, Inference, and Prediction, 2nd ed.; Springer Series in Statistics: Berlin/Heidelberg, Germany, 2009.

76. Lee, C.F. Tourist satisfaction with forest recreation experience: A segment-based approach. Anatolia 2015, 26, 535-548. [CrossRef]

77. Hair, J.F.; Anderson, R.E.; Tatham, R.L.; Black, W.C. Multivariate Data Analysis with Readings; Prentice-Hall: Upper Saddle River, NJ, USA, 2010.

78. Constantin, C.P. Principal Component Analysis-A powerful tool in computing marketing information. Bull. Transilv. Univ. Brasov. Ser. V Econ. Sci. 2014, 7, 25-30.

79. Constantin, C. A comparison between multivariate and bivariate analysis used in marketing research. Bull. Transilv. Univ. Brasov. Ser. V Econ. Sci. 2012, 5, 119-126.

80. Thuy, V.T.N.; Thao, H.D.P. Ecotourists' satisfaction and dissatisfaction: Asymmetric effects of service attributes. J. Asia Bus. Stud. 2019, 26, 189-205. [CrossRef]

81. Xu, L.; Ao, C.; Liu, B.; Cai, Z. Exploring the Influence of Multidimensional Tourist Satisfaction on Preferences for Wetland Ecotourism: A Case Study in Zhalong National Nature Reserve, China. Wetlands 2021, 41, 117. [CrossRef]

82. Hui, T.K.; Wan, D.; Ho, A. Tourists' satisfaction, recommendation and revisiting Singapore. Tour. Manag. 2007, $28,965-975$. [CrossRef]

83. Deng, J.; Li, J. Segmentation of Nature-Based Tourists in a Rural Area (2008-2009): A Single-Item Approach. Sustainability 2019, 11, 2052. [CrossRef]

84. Jensen, Ø.; Li, Y.; Uysal, M. Visitors' satisfaction at managed tourist attractions in Northern Norway: Do on-site factors matter? Tour. Manag. 2017, 63, 277-286. [CrossRef]

85. Goffi, G.; Cladera, M.; Pencarelli, T. Does sustainability matter to package tourists? The case of large-scale coastal tourism. Int. J. Tour. Res. 2019, 21, 544-559. [CrossRef]

86. Hasan, M.K.; Abdullah, S.K.; Lew, T.Y.; Islam, M.F. The antecedents of tourist attitudes to revisit and revisit intentions for coastal tourism. Int. J. Cult. Tour. 2019, 13, 218-234. [CrossRef]

87. Wood, M.E. Ecotourism: Principles, Practises E Policies for Sustainability; United Nations Publication: Paris, France, 2002.

88. Bădulescu, A.; Bâc, D. Profile of ecotourists in the Apuseni Mountains natural park. Geog. Tour. Geosites. 2009, 3, 7-16.

89. Dragan, A.A.; Toader, V.; Petrescu, D.C. Development potential of ecotourism in Romania and Europe: Links between a macroeconomic perspective and consumer profile. In Trends in Hospitality, Proceedings of the International Conference Entrepreneurship in the Hospitality Industry, Cluj-Napoca, Romania, 9-11 October 2014, 3rd ed.; Universitatea Babeş-Bolyai: Cluj-Napoca, Romania, 2014; pp. 135-145.

90. Hornoiu, R.I.; Pădurean, M.A.; Nica, A.-M.; Maha, L.-G. Tourism Consumption Behavior in Natural Protected Areas. Amfiteatru Econ. 2014, 16, 1178-1190.

91. Cong, L.C. A formative model of the relationship between destination quality, tourist satisfaction and intentional loyalty: An empirical test in Vietnam. J. Hosp. Tour. Manag. 2016, 26, 50-62. [CrossRef] 